\title{
Retraction
}

\section{Retraction for Karthikeyan et al., Random amplified polymorphic DNA analysis of genetic variability among isolates of Ganoderma species}

Retraction of "Random amplified polymorphic DNA analysis of genetic variability among isolates of Ganoderma species", by M. Karthikeyan, R. Bhaskaran, K. Radhika, S. Mathiyazhagan, R. Sandosskumar, R. Samiyappan and R. Velazhanan, which appeared in issue 5, October 2007, of the Journal of Plant Diseases and Protection.

I regret to inform that Dr. Jens Aumann, the managing editor of "Journal of Plant Diseases and Protection" made remarks and decision on my research paper entitled "Random amplified polymorphic DNA analysis of genetic variability among isolates of Ganoderma species" published in the Journal of Plant Diseases and Protection in Vol. 114 (5) pages 205-212 and indicated that the above article has been plagiarized from article entitled "Random Amplified Polymorphic DNA (RAPD) and Random Amplified Microsatellite (RAMS) of Ganoderma from infected Oil Palm and Coconut stumps in Malaysia" published by Latiffah Zakaria et al., (2005) in the Asia pacific journal of molecular Biology and Biotechnology. I submit to inform that this research work was actually carried out by me during my $\mathrm{PhD}$ thesis research work. In this study I have collected 31 isolates of Ganoderma sp from different parts of India and analyzed by RAPD. Because of better verbal english during my college days and non-availability of much literature in the above research area, I adopted some portion of the text including references from the above mentioned article published by Latiffah Zakaria et al., (2005). From my article itself it may be known that there differences in figures, materials and methods etc., I have not adopted any part of their result. I adopted their literature and a portion of the discussion for sustaining my results.

I am really sorry for the mistake, which I have committed. I also conveyed my apologies to Dr. Latiffah Zakaria and her co-workers. I have not done the things purposefully. I did not know the seriousness of the problem. I am really sorry for the mistake and excuse me for the bad things happened.

Dr. Samiyappan and co-authors of this article did not know the concerned article published in JPDP. Further I wish to state that I have submitted the article for publication without the concurrence from any of the co-authors. Hence they are not responsible on any way regarding the mistake which I have committed and I apologies for it.

I am extremely sorry for the mistake and I am solely responsible for the same. I am in the beginning of my research carrier, please consider my case, I will not commit such kind of mistake hereafter.

23 March 2009

M. Karthikeyan 